\title{
Identification of a novel mutation in CRYM in a Chinese family with hearing loss using whole-exome sequencing
}

\author{
MIN WANG, QIAN LI, ANCHUN DENG, XIANBAI ZHU and JUNJIE YANG \\ Department of Otorhinolaryngology and Head and Neck Surgery, Xinqiao Hospital, \\ Army Medical University (Third Military Medical University), Chongqing 400037, P.R. China
}

Received November 23, 2019; Accepted May 7, 2020

DOI: $10.3892 /$ etm.2020.8890

\begin{abstract}
Previous studies have identified 50 genes that contribute to non-syndromic autosomal dominant sensorineural deafness (DFNA). However, in numerous families with hearing loss, the specific gene mutation remains to be identified. In the present study, the clinical characteristics and gene mutations were analyzed in a Chinese pedigree with hereditary hearing loss. The clinical characteristics of the family members were assessed and a detailed audiology function examination was performed. Whole-exome sequencing (WES) was performed to identify the gene mutation responsible for the hearing loss. Sanger sequencing was used to verify the candidate mutation detected in the family. The family consisted of 31 members, seven of whom were diagnosed with sensorineural deafness of varying degrees. No mutation was identified by the general deafness gene chip. However, a novel heterozygous mutation in exon 3 (c.152C $>$ T; Pro51Leu) of the gene crystallin $\mu$ (CRYM) was identified by WES. This result was further verified by Sanger sequencing. Co-segregation of genotypes and phenotypes suggested that this novel mutation was instrumental for the hearing loss/DFNA. In conclusion, the present study identified a novel pathogenic mutation, NM_001888.5(CRYM): c.152C>T(Pro51Leu), associated with DFNA. This mutation has not been reported previously and further functional studies are warranted.
\end{abstract}

\section{Introduction}

Deafness is the most common sensory deficit disorder, accounting for a high incidence of disability (1). According to a survey from the World Health Organization (WHO) in 2013 , there are 360 million people with varying degrees

Correspondence to: Dr Anchun Deng, Department of Otorhinolaryngology and Head and Neck Surgery, Xinqiao Hospital, Army Medical University (Third Military Medical University), 183 Xinqiao Main Street, Shapingba, Chongqing 400037, P.R. China E-mail: 260019300@qq.com

Key words: sensorineural deafness, CRYM, mutation, sequencing of deafness worldwide (2). According to epidemiological data, $\sim 1$ in 1,000 newborns is diagnosed with congenital deafness (3). Deafness directly affects cognition, thinking and memory, resulting in a decline in the quality of life, thereby contributing to the burden of families and society (4). The progression and development of modern medicine have gradually reduced the proportion of deafness cases caused by environmental factors (5). However, the proportion of patients with hearing impairment caused by genetic factors has largely remained to be determined (6). Based on deafness combined with the presence or absence of malformations of the external ear, hereditary deafness may be classified into syndromic deafness and non-syndromic deafness (7). Nearly $70 \%$ of cases of hereditary deafness may be attributed to non-syndromic hearing loss (NSHL) and $50 \%$ of cases of NSHL have Mendelian disease (8). At present, 145 chromosomal loci are known to be associated with non-syndromic deafness (9). The coagulation factor $\mathrm{C}$ homology $(\mathrm{COCH})$ gene was the first gene to be identified to cause non-syndromic deafness (Online Mendelian Inheritance in Man ID, 603196) (10). Patients with a mutation in this gene may present with a series of symptoms caused by cochlear and vestibular dysfunction (11). At present, detection of the $\mathrm{COCH}$ mutation is a subject of intense research (12). Screening for gene mutations using traditional Sanger sequencing is time-consuming and expensive (13).

Recent developments in whole-exome sequencing (WES) technology have shifted this paradigm and currently, rapid sequencing of exomes, transcriptomes and genomes may be completed at a relatively low cost (14). Of note, the application of this technology to catalog the mutational landscapes of genetic disorders has revealed a novel approach to explore single-gene diseases $(15,16)$. The use of WES technology in patients with hereditary deafness and targeted next-generation sequencing of genes associated with deafness in hearing-impaired individuals has enabled the identification of informative mutations (17). WES is not only able to provide an efficient diagnosis for known deafness genes but also unravel novel gene mutations that may help us understand the molecular mechanism underlying deafness or hearing loss (18).

The present study aimed to identify genetic factors associated with hearing loss in a Chinese pedigree with hearing loss. WES was employed to identify a novel gene mutation in the gene crystallin $\mu$ (CRYM) that was accountable for the disease. 


\section{Materials and methods}

Subjects. The present study reported on familial non-syndromic autosomal dominant sensorineural deafness in four generations of a Chinese pedigree. The genealogical proband was a 35-year-old female, recruited from Xinqiao Hospital (Chongqing, China) of the Army Medical University in September 2015. This proband was subjected to pure-tone audiometry, Distortion Product Otoacoustic Emission (DPOAE) and Auditory Brainstem Response (ABR) evaluation. The test results were indicative of sensorineural deafness in the right ear and a high-frequency hearing loss in the left ear (Fig. 1). The results presented a progressive aggravation of hearing loss with increasing frequency illustrated by a downsloping of the hearing curve. The patient was diagnosed with sensorineural deafness according to the guidelines for clinical evaluation and etiologic diagnosis of hearing loss by the American College of Medical Genetics and Genomics (19). The patient and her family members were enrolled in the present study. The study protocol was approved by the Ethics Committee of Xinqiao Hospital (Chongqing, China) and the study was performed in accordance with the Declaration of Helsinki. Written informed consent was obtained from the proband and the remaining family members. Furthermore, all of the participants agreed to the publication of their results on clinical characteristics and genetic data with protection of their privacy. Subsequently, the detailed medical history was collected, including family history of deafness and consanguineous marriages, year of onset of deafness, age, progression, and history of ototoxic drugs and noise exposure.

DNA extraction. Whole blood samples of all subjects were collected and subjected to genomic DNA extraction using the RelaxGene Blood DNA System (Tiangen Biotech) as per the manufacturer's instructions. The extracted DNA was stored at $-20^{\circ} \mathrm{C}$ until further analysis.

Audiology function examination. An audiology function examination was performed using pure tone audiometry, DPOAE and ABR on all family members using standard procedures as described previously (20).

Gene chip detection analysis. A total of 15 mutations of four deafness-associated genes were detected, including those in gap junction protein beta 2 (GJB2; 35delG, 176del16, 235delC and 299delAT), GJB3 (538C $>$ T), solute carrier family 26 member $4(2168 \mathrm{~A}>\mathrm{G}, \mathrm{IVS} 7-2 \mathrm{~A}>\mathrm{G}, 1174 \mathrm{~A}>\mathrm{T}, 122 \mathrm{G}>\mathrm{A}, 1229 \mathrm{C}>\mathrm{T}$, $1975 \mathrm{G}>\mathrm{C}, 2027 \mathrm{~T}>\mathrm{A}$ and IVS15+5 $\mathrm{G}>\mathrm{A}$ ) and mitochondrial $12 \mathrm{~S}$ ribosomal RNA $(1494 \mathrm{C}>\mathrm{T}$ and $1555 \mathrm{~A}>\mathrm{G})$ using the Heredity Hearing Loss Array Detection Kit purchased from Capital Bio Corp. The chip was imaged using a LuxScan ${ }^{\mathrm{TM}}$ 10 KB Microarray Scanner (Capital Bio Corp.) (21). Data evaluation was performed using SPSS 19.0 (IBM Corp.).

WES analysis. Specific primer sequences were designed by Primer Premier 5.0 (Premier Biosoft International). The Ion $\mathrm{PI}^{\mathrm{TM}}$ Hi-Q ${ }^{\mathrm{TM}}$ Sequencing $200 \mathrm{Kit}$ (Thermo Fisher Scientific, Inc.) was employed for target gene mutation detection by computational mapping analysis. Genomic DNA samples were sheared by sonication. The sheared genomic DNA was then hybridized with the NimbleGen 2.0 probe sequence capture array from Roche (http://www.nimblegen.com/products/seqcap/ez/v2/index.html) to enrich the exonic DNA (Joy Orient). The libraries were first tested for exon-enrichment by quantitative PCR and for size distribution and concentration using the Agilent Bioanalyzer 2100 (Agilent Technologies, Inc.). The samples were then sequenced on an Illumina Hiseq 2500 platform (Illumina, Inc.). Each sample was tested in two parallel reactions.

\section{Results}

Family investigation and clinical phenotype. The pedigree chart is presented in Fig. 2. The family consisted of 31 members belonging to four generations. There were 14 males and 17 females. All family members underwent pure-tone audiometry examinations and the results are listed in Table I. A total of 7 patients, aged 31-79 years, were diagnosed with sensorineural deafness of varying degrees. None of the patients had a history of ototoxic drug exposure. Among them, cases $\mathrm{I}_{1}, \mathrm{II}_{3}$ and $\mathrm{II}_{4}$ were diagnosed with severe deafness on both ears. Cases $\mathrm{III}_{2}, \mathrm{III}_{9}$ and $\mathrm{III}_{14}$ demonstrated mild sensorineural deafness. Case $\mathrm{II}_{6}$ had mixed deafness (conductive deafness and sensory deafness) on the right ear and sensorineural deafness on the left ear. The results of the hearing test for the remaining family members are listed in Supplementary Table SI. There was no predilection for sex and a significant phenomenon of continuous transmission was noted. At least one parent of affected subjects was diagnosed with deafness, suggesting that the disease had an autosomal dominant pattern of inheritance.

Gene chip identification of deafness-associated genes. The routine diagnosis of deafness genes was performed by microarray in order to identify hot mutations in the study subjects. The gene chip contained 4 genes and 15 loci. The details of the gene chip and the mutations it is able to detect are listed in Table II. However, none of these mutations was identified by the gene chip in any of the participants.

Mutation identified by WES. WES was performed in four family members, namely cases $\mathrm{III}_{2}, \mathrm{III}_{14}, \mathrm{IV}_{2}$ and $\mathrm{IV}_{8}$. A heterozygous mutation of CRYM was detected in cases $\mathrm{III}_{2}$ and $\mathrm{III}_{14}$; however, it was absent in subjects $\mathrm{IV}_{2}$ and $\mathrm{IV}_{8}$. The heterozygous mutation detected was $\mathrm{c} .152 \mathrm{C}>\mathrm{T}$ (Pro51Leu). However, no mutations in other known genes associated with deafness were observed. Whether the mutation was pathogenic and accounted for a familial trait remain to be verified. Sanger sequencing was used to verify the results obtained by WES in the remaining family members participating in the study. Of note, the CRYM mutation was identified in all other seven family members with deafness, as in the proband $\mathrm{III}_{2}$ (Fig. 3).

Bioinformatics analysis. PolyPhen-2 (http://genetics.bwh. harvard.edu/pph2/) was used to predict the possible impact of an amino acid substitution on the structure and function of the mutation, which indicated that the CRYM c.152C $>\mathrm{T}$ (Pro51Leu) mutation is probably damaging, with a score of 1.000 (sensitivity, 0.00; specificity, 1.00), and the Protein Variation Effect Analyzer (http://provean.jcvi.org/index.php) indicated 

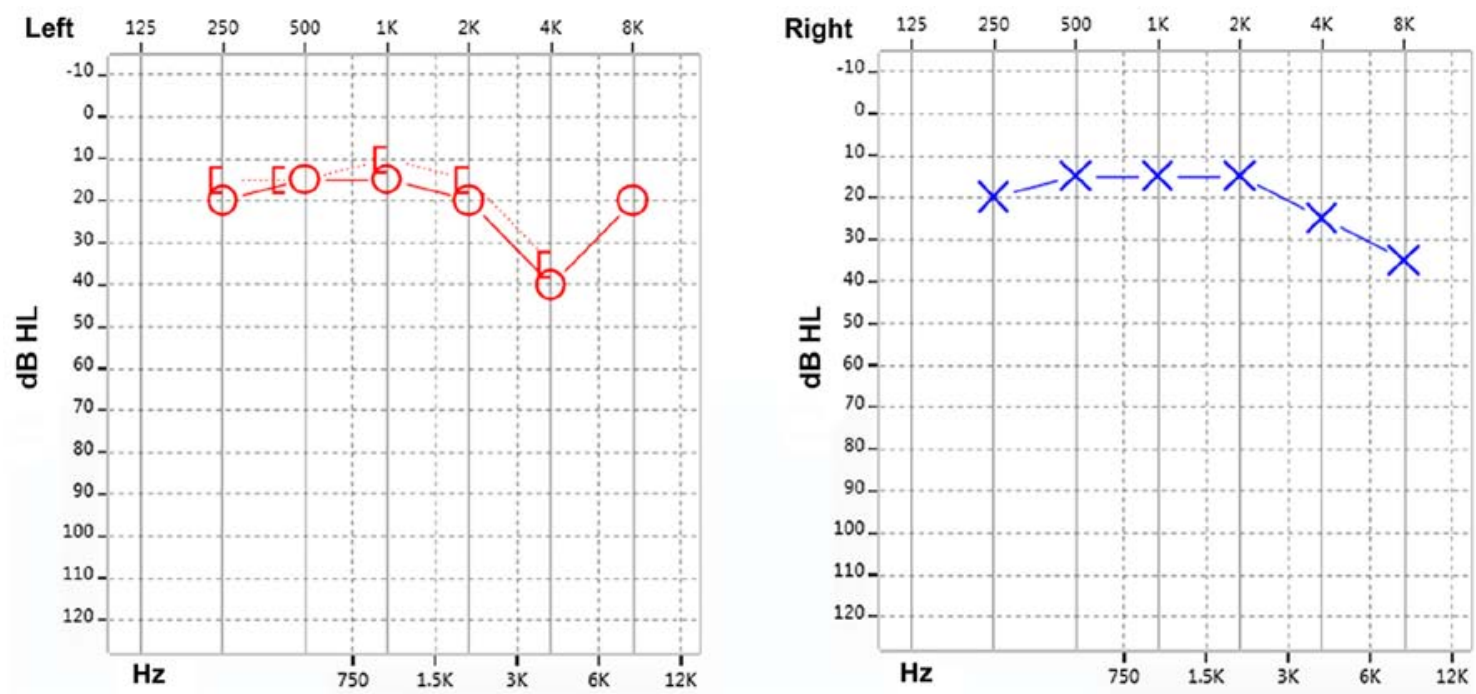

Figure 1. Results of the audiogram function test for the proband. dB, decibels; HL, hearing level.

I

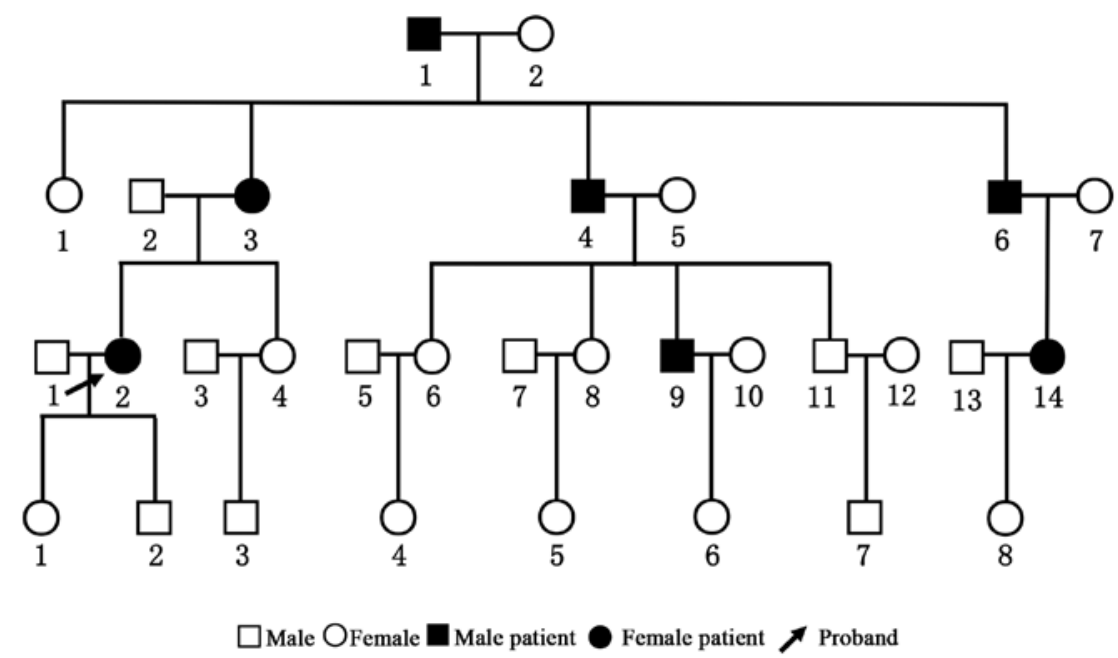

Figure 2. Pedigree chart of the family with the c.152C>T mutation in CRYM.

a deleterious effect with a score of -5.395 (score below -2.5 means deleterious effect). Collectively, these results strongly indicated that the p.P51L mutation was likely to be deleterious to the protein. The result of a multiple sequence alignment suggested that the proline at position 51 of CRYM is highly conserved among various species (Fig. 4). In addition, the 3-dimensional protein structures were predicted and displayed with a cartoon, a cartoon/spheres and a surface model, which were generated using PyMOL software (version 2.3; Schrödinger LLC; Fig. 5). The protein structure parameters indicated that The Inertia Axis Aligned Bounding Box (IABB) dimensions were $(43.63,47.33,63.49)$ and $(43.32,47.22,63.49)$ and the IABB volume was $131,101.14$ and $129,861.34$ for the wild-type and muted type, respectively. This indicates that this substitution is able to destabilize the protein conformation.

Follow-up. The only follow-up of the proband was by a phone call after 4 years. The subjective sensation of her hearing was not significantly changed according to the telephone survey and answered a subjective questionnaire with the help of her family member. No further hearing examinations were completed on the other family members and no family members were prescribed hearing aids.

\section{Discussion}

In the present study, a Chinese pedigree with hereditary sensorineural hearing loss of unknown genetic etiology was analyzed for a causative mutation using WES. A novel mutation, NM_00188.5(CRYM): c.152C $>\mathrm{T}$ (Pro51Leu), was detected. This mutation, not being a common variant, has a high likelihood of being pathogenic in patients with sensorineural hearing loss.

Deafness is a hereditary disorder with a high degree of genetic heterogeneity. DFNA is primarily the result of a single gene mutation (22). To date, a total of 105 genes have been reported to be associated with NSHL (23). Among the genes linked to this condition, $\mathrm{COCH}$ was the first gene to be reported to be associated with vestibular function (24). Clinical symptoms of $\mathrm{COCH}$ mutation are autosomal 
Table I. Clinical characteristics of the family members.

\begin{tabular}{|c|c|c|c|c|c|c|c|}
\hline Subject & $\begin{array}{c}\text { Age } \\
\text { (years) }\end{array}$ & Sex & $\begin{array}{l}\text { Age at } \\
\text { onset } \\
\text { (years) }\end{array}$ & Pure tone test & Degree of hearing loss & DPOAE & $\begin{array}{l}\text { Binaural } \\
\text { ABR threshold } \\
\quad(\mathrm{dBnHL})\end{array}$ \\
\hline I1 & 78 & Male & 47 & $\begin{array}{l}\text { Binaural full frequency } \\
\text { sensorineural deafness }\end{array}$ & $\begin{array}{l}\text { High severity on both } \\
\text { sides }\end{array}$ & $\begin{array}{l}\text { Binaural full frequency } \\
\text { extraction in abnormal } \\
\text { range }\end{array}$ & 110 \\
\hline II 2 & 56 & Male & 54 & $\begin{array}{l}\text { Binaural sensorineural } \\
\text { deafness }\end{array}$ & $\begin{array}{l}\text { Moderate on both } \\
\text { sides }\end{array}$ & $\begin{array}{l}\text { Binaural full frequency } \\
\text { extraction in abnormal } \\
\text { range }\end{array}$ & 50 \\
\hline III & 61 & Female & 52 & Binaural mixed deafness & Severe on both sides & $\begin{array}{l}\text { Binaural full frequency } \\
\text { extraction in abnormal } \\
\text { range }\end{array}$ & 70 \\
\hline II4 & 56 & Male & 43 & $\begin{array}{l}\text { Binaural sensorineural } \\
\text { deafness }\end{array}$ & Severe on both sides & $\begin{array}{l}\text { Binaural full frequency } \\
\text { extraction in abnormal } \\
\text { range }\end{array}$ & 100 \\
\hline II6 & 56 & Male & 50 & Binaural mixed deafness & Severe on both sides & $\begin{array}{l}\text { Binaural full frequency } \\
\text { extraction in abnormal } \\
\text { range }\end{array}$ & 70 \\
\hline III2 & 35 & Female & 32 & $\begin{array}{l}\text { Sensorineural deafness in } \\
\text { right ear, high-frequency } \\
\text { hearing loss in left ear }\end{array}$ & $\begin{array}{l}\text { Normal hearing } \\
\text { threshold }\end{array}$ & $\begin{array}{l}\text { Binaural partial frequency } \\
\text { extraction in abnormal } \\
\text { range }\end{array}$ & 30 \\
\hline III9 & 31 & Male & 31 & $\begin{array}{l}\text { Binaural sensorineural } \\
\text { deafness with high } \\
\text { frequency }\end{array}$ & $\begin{array}{l}\text { Normal hearing } \\
\text { threshold }\end{array}$ & $\begin{array}{l}\text { Binaural partial frequency } \\
\text { extraction in abnormal } \\
\text { range }\end{array}$ & 30 \\
\hline III14 & 32 & Female & 31 & $\begin{array}{l}\text { Binaural sensorineural } \\
\text { deafness with high } \\
\text { frequency }\end{array}$ & $\begin{array}{l}\text { Normal hearing } \\
\text { threshold }\end{array}$ & $\begin{array}{l}\text { Binaural partial frequency } \\
\text { extraction in abnormal } \\
\text { range }\end{array}$ & 40 \\
\hline
\end{tabular}

DPOAE, Distortion Product Otoacoustic Emission; ABR, Auditory Brainstem Response; dBnHL, decibel normal hearing level.

Table II. General deafness gene chip for target capture.

\begin{tabular}{ll}
\hline Gene & \multicolumn{1}{c}{ Variant } \\
\hline GJB2 & NM_004004.6:c.35delG \\
GJB2 & 176 del16 \\
GJB2 & 235delC \\
GJB2 & 299delAT \\
GJB3 & NM_024009.3:c.538C $>$ T \\
SLC26A4 & 2168A $>$ G \\
SLC26A4 & NM_000441.2:c.919-2A $>$ G \\
SLC26A4 & $1174 A>T$ \\
SLC26A4 & $1226 G>A$ \\
SLC26A4 & $1229 \mathrm{C}>\mathrm{T}$ \\
SLC26A4 & $1975 G>C$ \\
SLC26A4 & $2027 T>A$ \\
SLC26A4 & NM_000441.2:c.1707+5G $>$ A \\
MT-RNR1 & $1494 C>T$ \\
MT-RNR1 & $1555 A>G$
\end{tabular}

GJB2, gap junction protein $\beta 2$; SLC26A4, solute carrier family 26 member 4; MT-RNR1, mitochondrially encoded $12 \mathrm{~S}$ ribosomal RNA. dominant, non-syndromic and characterized by progressive sensorineural hearing loss (10). At onset, the disease involves high-frequency hearing impairment. It progresses with age to severe hearing loss affecting low and high frequencies (25).

Recently, with the advent of comprehensive genetic testing for hereditary hearing loss using massively parallel sequencing (26), further gene mutations accounting for NSHL have been identified, thereby highlighting its genetic heterogeneity (27). The application of a deafness diagnostic screening panel based on a deafness mutations/gene database has gained popularity (28). A gene diagnostic chip for hereditary deafness has been used previously to detect gene mutations associated with hearing impairment among high-risk pregnant females (29) and newborns (30), and for pre-natal diagnosis of deafness to avoid the birth of children with congenital deafness (31).

At present, gene chip is used for rapid genetic diagnosis and in epidemiological surveys of hearing loss. However, it was originally devised for hot-spot mutations that have already been reported. Therefore, it cannot be used to detect other mutations in these genes. With the rapid development of WES technology, the scientific community has begun to widely adopt second-generation sequencing technology to solve biological problems. This novel generation of sequencers 
$\mathbf{I}_{1}$
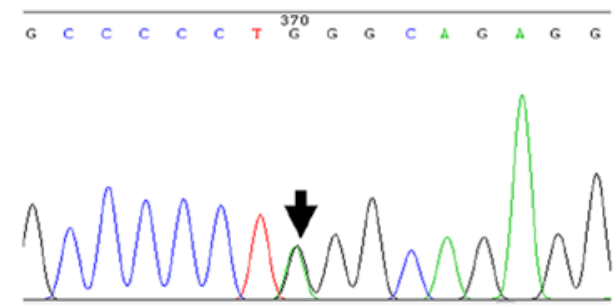

II $_{4}$

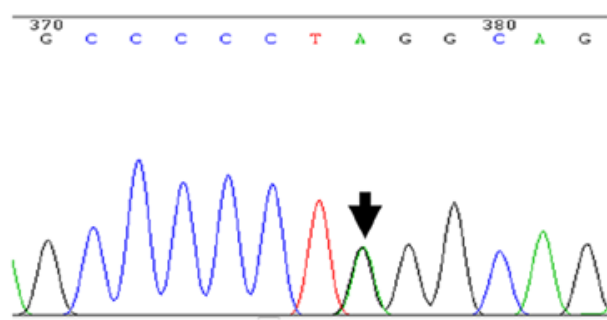

III $_{2}$
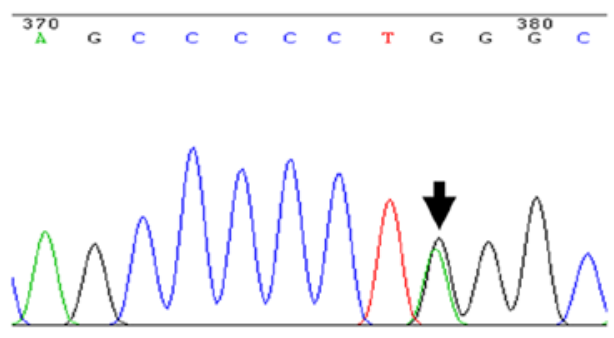

II $_{3}$
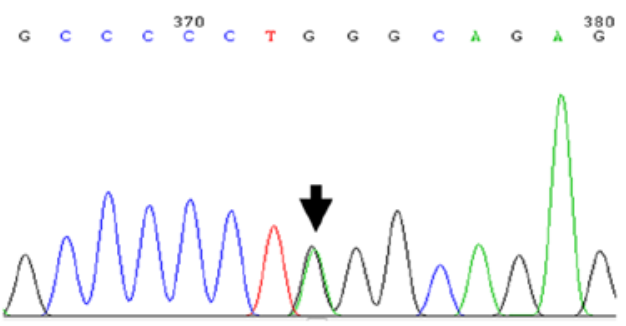

II $_{6}$

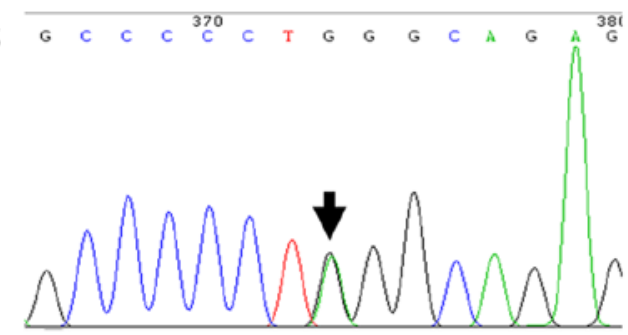

III

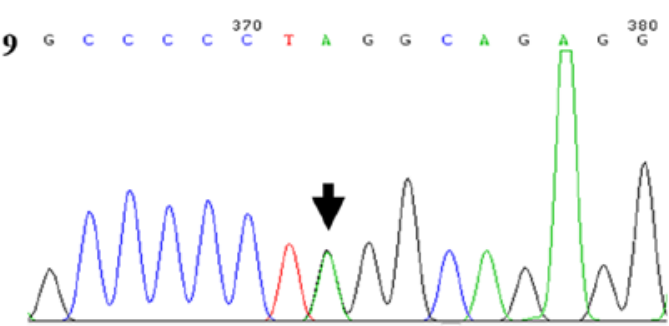

III

14 370 C C C C C C C T T G G G

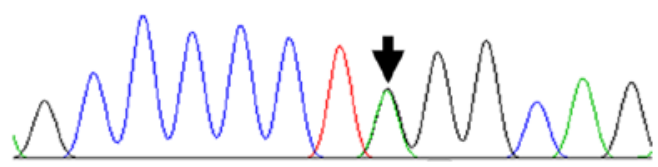

Figure 3. Results of the direct Sanger sequencing of the crystallin $\mu$ gene in seven patients with dominant sensorineural deafness. The mutation site is indicated by black arrows.

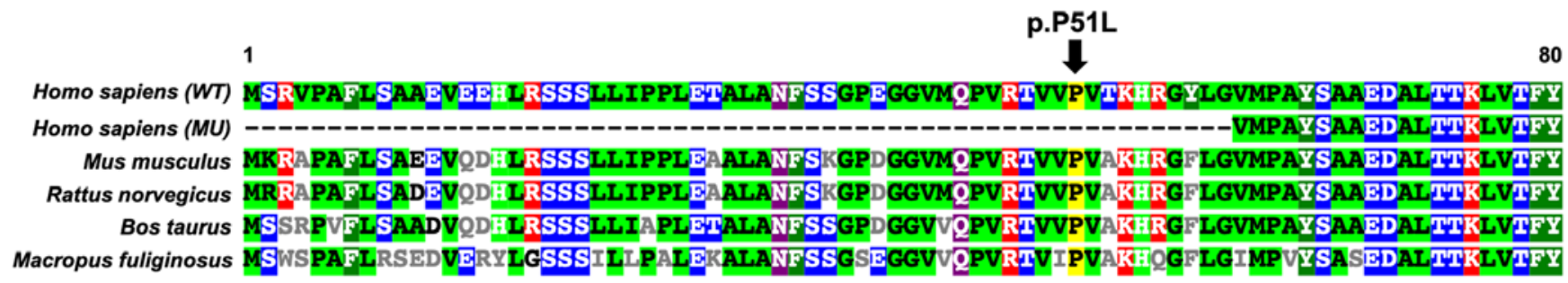

Figure 4. Conservation analysis of the crystallin $\mu$ gene. The mutation site is indicated by a black arrow. WT, wild-type; Mu, mutant.

is able to rapidly sequence whole genomes and zoom in to deeply sequence the target regions of interest (32). Numerous genetic variants of unknown significance may be detected in patients by WES. In the present study, a regular gene chip was used to screen mutations for hearing loss, although no positive results were obtained. However, with the application of NGS, a novel mutation of CRYM, c.152C>T(Pro51Leu), responsible for hearing impairment was identified.
CRYM, which is also termed Thyroid Hormone Binding Protein (THBP) or Deafness, autosomal dominant, 40 (DFNA40), is located on chromosome 16. Its transcript length is $1,482 \mathrm{bp}$ with eight exons encoding 314 amino acids. CRYM is mainly expressed in the heart and brain. It is particularly abundant in the inner ear (33). A previous study has demonstrated that CRYM is expressed in the human cochlea (34). CRYM has a critical role in the physiological regulation of 
Table III. Summary of mutations in the crystallin $\mu$ gene and the clinical significance of pedigrees with associated dominant sensorineural deafness.

\begin{tabular}{|c|c|c|c|}
\hline Nucleic acid mutation & Amino acid variation & Molecular consequence & Clinical significance \\
\hline c. $945 \mathrm{~A}>\mathrm{T}$ & p.Ter315Tyr & Single nucleotide variant & Pathogenic \\
\hline c. $941 \mathrm{~A}>\mathrm{C}$ & p.Lys314Thr & Missense & Pathogenic \\
\hline c. $907 \mathrm{G}>\mathrm{A}$ & p.Ala303Thr & Missense & Uncertain significance \\
\hline c. $864 \mathrm{C}>\mathrm{G}$ & p.Thr288= & Single nucleotide variant & Benign \\
\hline c. $807 \mathrm{~T}>\mathrm{C}$ & p.Phe269= & Single nucleotide variant & Benign/likely benign \\
\hline c. $761 \mathrm{C}>\mathrm{T}$ & p.Ala254Val & Missense & Uncertain significance \\
\hline c. $741 \mathrm{C}>\mathrm{T}$ & p.Tyr247= & Single nucleotide variant & Benign \\
\hline c. $662 \mathrm{C}>\mathrm{T}$ & p.Ala221 Val & Missense & Likely benign \\
\hline c. $.580 \mathrm{G}>\mathrm{A}$ & p.Ala194Thr & Missense & Uncertain significance \\
\hline c.523_524delinsTT & p.Glu175Leu & Missense & Conflicting interpretations of pathogenicity \\
\hline c. $490-12 \mathrm{C}>\mathrm{T}$ & & Single nucleotide variant & Benign \\
\hline c. $489+9 A>G$ & & Single nucleotide variant & Likely benign \\
\hline c. $480 \mathrm{C}>\mathrm{T}$ & p.Ser160= & Single nucleotide variant & Likely benign \\
\hline c. $479 \mathrm{C}>\mathrm{T}$ & p.Ser160Phe & Missense & Uncertain significance \\
\hline c. $474 \mathrm{G}>\mathrm{A}$ & p.Gln $158=$ & Single nucleotide variant & Uncertain significance \\
\hline c. $343 \mathrm{~A}>\mathrm{G}$ & p.Ile115Val & Missense & Uncertain significance \\
\hline c. $325-12 \mathrm{~T}>\mathrm{C}$ & & Single nucleotide variant & Benign \\
\hline c. $279 \mathrm{G}>\mathrm{A}$ & p.Gln93= & Single nucleotide variant & Likely benign \\
\hline c. $135 \mathrm{C}>\mathrm{A}$ & p.Pro45= & Single nucleotide variant & Likely benign \\
\hline c. $108 \mathrm{C}>\mathrm{A}$ & p.Ser36Arg & Missense & Conflicting interpretations of pathogenicity \\
\hline c. $8 \mathrm{G}>\mathrm{T}$ & p.Arg3Leu & Missense & Uncertain significance \\
\hline
\end{tabular}

CRYM p.P51L

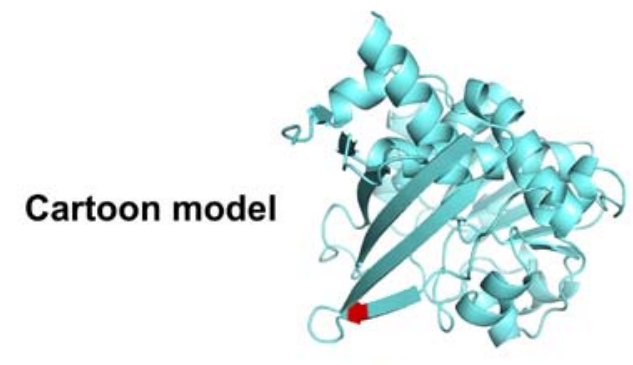

Cartoon/spheres model

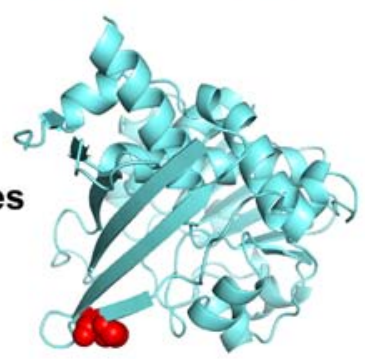

Surface model

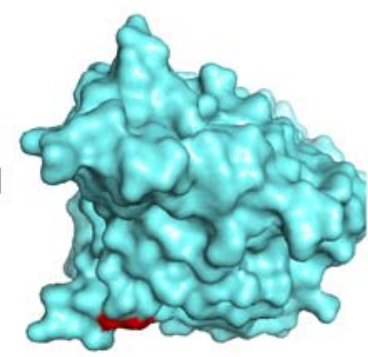

CRYM wild type
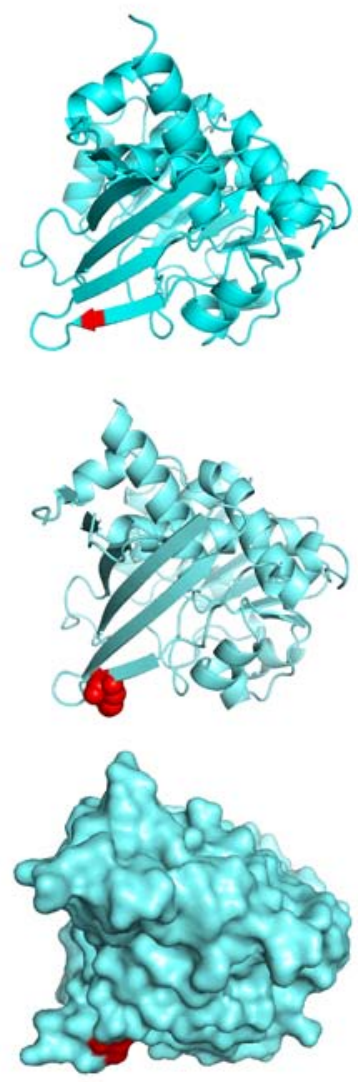

Figure 5. Display of the predicted 3-dimensional protein structure of CRYM. The red colour indicated the amino acid mutation site. CRYM, crystallin $\mu$. 
the activity of thyroid hormone (35). An experimental study has indicated that CRYM may have a role in the development of cortical and hippocampal pyramidal cells in the early postnatal period (36). Furthermore, CRYM expression is possibly upregulated through the activator protein-1 (AP-1) site in the promoter (37). Another important CRYM function has also been identified: When combined with ketimine reductase, it may act as a classical imine reductase (38). In addition, CRYM has a critical role and is regarded as a novel androgen-regulated gene whose expression is elevated in prostate cancer (39). It has been demonstrated in an animal model that CRYM mutations cause auditory dysfunction through thyroid hormone-binding effects on the cochlea (40). It is well known that thyroid hormone is crucial for normal development, as well as maintenance of hearing function (41). CRYM is divided into two classes: Taxon-specific and ubiquitous. This gene encodes a taxon-specific crystallin protein that binds NADPH and has a sequence similarity to bacterial ornithine cyclodeaminases, which is particularly abundant in kangaroo lenses (42).

To date, CRYM-null patients have not been reported (35). Abe et al (43) were the first to demonstrate that CRYM mutation is associated with hearing loss. In their study, they indicated that one missense and one stop-lost variant in CRYM was a pathogenic mutation for hearing loss in two different families of Japanese origin. A search for the CRYM mutation in Clinvar was performed (https://www.ncbi.nlm. nih.gov/clinvar/?term=CRYM\%5Bgene\%5D). Most of the identified mutations in other loci of CRYM were benign, of uncertain significance or had conflicting interpretations of pathogenicity. The details of the mutations identified are listed in Table III. The previously unreported novel CRYM mutation identified in the present study is likely to be pathogenic.

In conclusion, the present study identified a novel mutation, NM_00188.5(CRYM): c.152C >T(Pro51Leu), which further strengthened the association between CRYM mutation and NSHL. Further functional studies regarding mutations in this clinical condition may assist in clarifying the pathogenic mechanism underlying familial sensorineural deafness.

\section{Acknowledgements}

Not applicable.

\section{Funding}

No funding received.

\section{Availability of data and materials}

The datasets used and/or analyzed during the current study are available from the corresponding author on reasonable request.

\section{Authors' contributions}

AD designed the study; QL performed all of the experiments; $\mathrm{XZ}$ and JY carried out the audiology function examination; MW collected the clinical data, analyzed the data, and prepared the manuscript. All authors have read and approved the final version of the manuscript.

\section{Ethics approval and consent to participate}

The study protocol was approved by the Ethics Committee of Xinqiao Hospital (Chongqing, China) and the study was performed in accordance with the Declaration of Helsinki. Written informed consent was obtained from the proband and the remaining family members.

\section{Patient consent for publication}

All of the participants agreed to the publication of their results on clinical characteristics and genetic data with protection of their privacy.

\section{Competing interests}

The authors declare that they have no competing interests.

\section{References}

1. Sheffield AM and Smith RJH: The epidemiology of deafness. Cold Spring Harb Perspect Med 9: a033258, 2019.

2. Chadha S and Cieza A: World Health Organization and its initiative for ear and hearing care. Otolaryngol Clin North Am 51: 535-542, 2018.

3. Yao GD, Li SX, Chen DL, Feng HQ, Zhao SB, Liu YJ, Guo LL, Yang ZM, Zhang XF, Sun CX, et al: Combination of hearing screening and genetic screening for deafness-susceptibility genes in newborns. Exp Ther Med 7: 218-222, 2014.

4. Lin FR, Yaffe K, Xia J, Xue QL, Harris TB, Purchase-Helzner E Satterfield S, Ayonayon HN, Ferrucci L, Simonsick EM, et al: Hearing loss and cognitive decline in older adults. JAMA Intern Med 173: 293-299, 2013.

5. Lasak JM, Allen P, McVay T and Lewis D: Hearing loss: Diagnosis and management. Primary Care 41: 19-31, 2014.

6. Momi SK, Wolber LE, Fabiane SM, MacGregor AJ and Williams FM: Genetic and environmental factors in age-related hearing impairment. Twin Res Hum Genet 18: 383-392, 2015

7. Kremer H: Hereditary hearing loss; about the known and the unknown. Hear Res 376: 58-68, 2019.

8. Vona B, Müller M, Dofek S, Holderried M, Löwenheim H and Tropitzsch A: A big data perspective on the genomics of hearing loss. Laryngorhinootologie 98 (Suppl 1): S32-S81, 2019 (In English, German).

9. Petersen $M$ and Willems P: Non-syndromic, autosomal-recessive deafness. Clin Genet 69: 371-392, 2006.

10. Robertson NG, Lu L, Heller S, Merchant SN, Eavey RD, McKenna M, Nadol JB Jr, Miyamoto RT, Linthicum FH Jr, Lubianca Neto JF, et al: Mutations in a novel cochlear gene cause DFNA9, a human nonsyndromic deafness with vestibular dysfunction. Nat Genet 20: 299-303, 1998.

11. Khetarpal U: DFNA9 is a progressive audiovestibular dysfunction with a microfibrillar deposit in the inner ear. Laryngoscope 110: 1379-1384, 2000

12. JanssensdeVarebeke S, Topsakal V, Van Camp G and Van Rompaey V: A systematic review of hearing and vestibular function in carriers of the Pro51Ser mutation in the $\mathrm{COCH}$ gene. Eur Arch Otorhinolaryngol 276: 1251-1262, 2019.

13. Ku C, Cooper DN, Iacopetta B and Roukos DH: Integrating next-generation sequencing into the diagnostic testing of inherited cancer predisposition. Clin Genet 83: 2-6, 2013.

14. Levy SE and Myers RM: Advancements in next-generation sequencing. Annu Rev Genomics Hum Genet 17: 95-115, 2016.

15. Boycott KM, Vanstone MR, Bulman DE and MacKenzie AE: Rare-disease genetics in the era of next-generation sequencing: Discovery to translation. Nat Rev Genet 14: 681-691, 2013.

16. Mardis ER: The impact of next-generation sequencing technology on genetics. Trends Genet 24: 133-141, 2008.

17. Vona B, Müller T, Nanda I, Neuner C, Hofrichter MA, Schröder J, Bartsch O, Läßig A, Keilmann A, Schraven S, et al: Targeted next-generation sequencing of deafness genes in hearing-impaired individuals uncovers informative mutations. Genet Med 16: 945-953, 2014. 
18. Yang T, Wei X, Chai Y, Li L and Wu H: Genetic etiology study of the non-syndromic deafness in Chinese Hans by targeted next-generation sequencing. Orphanet J Rare Dis 8: 85, 2013.

19. Alford RL, Arnos KS, Fox M, Lin JW, Palmer CG, Pandya A, Rehm HL, Robin NH, Scott DA, Yoshinaga-Itano C, et al: American College of Medical Genetics and Genomics guideline for the clinical evaluation and etiologic diagnosis of hearing loss. Genet Med 16: 347-355, 2014.

20. Mehraei G, Gallardo AP, Shinn-Cunningham BG and Dau T: Auditory brainstem response latency in forward masking, a marker of sensory deficits in listeners with normal hearing thresholds. Hear Res 346: 34-44, 2017.

21. Yan D, Xiang G, Chai X, Qing J, Shang H, Zou B, Mittal R, Shen J, Smith RJ, Fan YS, et al: Screening of deafness-causing DNA variants that are common in patients of European ancestry using a microarray-based approach. PLoS One 12: e0169219, 2017.

22. Nance WE: The genetics of deafness. Ment Retard Dev Disabil Res Rev 9: 109-119, 2003.

23. DiStefano MT, Hemphill SE, Oza AM, Siegert RK, Grant AR, Hughes MY, Cushman BJ, Azaiez H, Booth KT, Chapin A, et al: ClinGen expert clinical validity curation of 164 hearing loss gene-disease pairs. Genet Med 21: 2239-2247, 2019.

24. de Kok YJ, Bom SJ, Brunt TM, Kemperman MH, van Beusekom E, van der Velde-Visser SD, Robertson NG, Morton CC, Huygen PL, Verhagen WI, et al: A Pro51Ser mutation in the $\mathrm{COCH}$ gene is associated with late onset autosomal dominant progressive sensorineural hearing loss with vestibular defects. Hum Mol Genet 8: 361-366, 1999.

25. Kemperman MH, Bom SJ, Lemaire FX, Verhagen WI, Huygen PL and Cremers CW: DFNA9/COCH and its phenotype. Nat Genet 61: 66-72, 2002.

26. Shearer AE, DeLuca AP, Hildebrand MS, Taylor KR, Gurrola J II, Scherer S, Scheetz TE and Smith RJ: Comprehensive genetic testing for hereditary hearing loss using massively parallel sequencing. Proc Natl Acad Sci USA 107: 21104-21109, 2010.

27. Hilgert N, Smith RJ and Camp GV: Function and expression pattern of nonsyndromic deafness genes. Curr Mol Med 9: 546-564, 2009

28. Abe S, Yamaguchi T and Usami SI: Application of deafness diagnostic screening panel based on deafness mutation/gene database using invader assay. Genet Test 11: 333-340, 2007.

29. Fang Y, Gu MS, Suo F, Wang CX, Liu XH and Liu FM: Application of gene detection technique in the antenatal diagnosis of hereditary hearing loss. Eur Rev Med Pharmacol Sci 21: 1452-1455, 2017.

30. He X, Li X, Guo Y, Zhao Y, Dong H, Dong J, Zhong L, Shi Z, Zhang Y, Soliman M, et al: Newborn screening of genetic mutations in common deafness genes with bloodspot-based gene chip array. Am J Audiol 27: 57-66, 2018.

31. Atik T, Bademci G, Diaz-Horta O, Blanton SH and Tekin M: Whole-exome sequencing and its impact in hereditary hearing loss. Genet Res (Camb) 97: e4, 2015.

32. Margulies M, Egholm M, Altman WE, Attiya S, Bader JS, Bemben LA, Berka J, Braverman MS, Chen YJ, Chen Z, et al: Genome sequencing in microfabricated high-density picolitre reactors. Nature 437: 376-380, 2005.
33. Schrauwen I, Hasin-Brumshtein Y, Corneveaux JJ, Ohmen J, White C, Allen AN, Lusis AJ, Van Camp G, Huentelman MJ and Friedman RA: A comprehensive catalogue of the coding and non-coding transcripts of the human inner ear. Hear Res 333: 266-274, 2016

34. Usami S, Takumi Y, Suzuki N, Oguchi T, Oshima A, Suzuki H, Kitoh R, Abe S, Sasaki A and Matsubara A: The localization of proteins encoded by CRYM, KIAA1199, UBA52, COL9A3, and COL9A1, genes highly expressed in the cochlea. Neuroscience 154: 22-28, 2008.

35. Suzuki S, Mori JI and Hashizume K: Mu-crystallin, a NADPH-dependent T(3)-binding protein in cytosol. Trends Endocrinol Metab 18: 286-289, 2007.

36. Hommyo R, Suzuki SO, Abolhassani N, Hamasaki H, Shijo M, Maeda N, Honda H, Nakabeppu Y and Iwaki T: Expression of CRYM in different rat organs during development and its decreased expression in degenerating pyramidal tracts in amyotrophic lateral sclerosis. Neuropathology 38: 247-259, 2018.

37. Suzuki S, Nishio SI, Ishii H, Sekido T, Takeshige K, Ohkubo Y, Hiwatashi D, Takeda T and Komatsu M: Possible roles of the AP-1 site in the cytosolic T3 binding protein promoter and insights into its physiological significance. Horm Metab Res 45: 501-506, 2013.

38. Hallen A, Cooper AJ, Smith JR, Jamie JF and Karuso P: Ketimine reductase/CRYM catalyzes reductive alkylamination of $\alpha$-keto acids, confirming its function as an imine reductase. Amino Acids 47: 2457-2461, 2015.

39. Malinowska K, Cavarretta IT, Susani M, Wrulich OA, Uberall F, Kenner L and Culig Z: Identification of mu-crystallin as an androgen-regulated gene in human prostate cancer. Prostate 69: 1109-1118, 2009.

40. Oshima A, Suzuki S, Takumi Y, Hashizume K, Abe S and Usami S: CRYM mutations cause deafness through thyroid hormone binding properties in the fibrocytes of the cochlea. J Med Genet 43: e25, 2006.

41. Griffith AJ, Szymko YM, Kaneshige M, Quiñónez RE, Kaneshige K, Heintz KA, Mastroianni MA, Kelley MW and Cheng SY: Knock-in mouse model for resistance to thyroid hormone (RTH): An RTH mutation in the thyroid hormone receptor beta gene disrupts cochlear morphogenesis. J Assoc Res Otolaryngol 3: 279-288, 2002.

42. Wistow G: Lens crystallins: Gene recruitment and evolutionary dynamism. Trends Biochem Sci 18: 301-306, 1993.

43. Abe S, Katagiri T, Saito-Hisaminato A, Usami S, Inoue Y, Tsunoda $T$ and Nakamura Y: Identification of CRYM as a candidate responsible for nonsyndromic deafness, through cDNA microarray analysis of human cochlear and vestibular tissues. Am J Hum Genet 72: 73-82, 2003.

This work is licensed under a Creative Commons Attribution-NonCommercial-NoDerivatives 4.0 International (CC BY-NC-ND 4.0) License. 